\title{
Treatment of keratoectasia after LASIK by intrastromal corneal ring segments in two patients who had no preoperative risk factors
}

This article was published in the following Dove Press journal:

Clinical Ophthalmology

10 July 2010

Number of times this article has been viewed

\author{
Minoru Tomita \\ Naoko Inoue \\ Tadahiko Tsuru \\ Shinagawa LASIK Center, \\ Tokyo, Japan
}

Correspondence: Minoru Tomita Shinagawa LASIK Center,Yurakucho ITOCiA I3-I5F 2-7-I Yurakucho Chiyoda-ku, Tokyo 100-0006 Japan Tel $+8 \mid 3522$ I 2207

Fax +81352218138

Email tomita@shinagawa.com
Purpose: To report on keratoectasia after laser in situ keratomileusis (LASIK) in two eyes of two patients who had no obvious preoperative risk factors, and treatment of keratoectasia by intrastromal corneal ring segments.

Method: Clinical interventional case report.

Results: Two patients underwent LASIK in both eyes at Shinagawa LASIK center, Tokyo. Preoperative standard ophthalmological examinations demonstrated no specific risk factors of keratoectasia. However, each eye of the two patients developed keratoectasia as defined by corneal topography. Treatment for keratoectasia was performed by inserting intrastromal corneal ring segments (ICRS) in the affected eyes. In one eye, KeraRing (MEDIPHACOS, Ltd, Brazil) was inserted, and Intacs SK (Addition Technology Inc, USA) was inserted in the other.

Conclusion: Even in eyes where no risk factors for keratoectasia were found following thorough preoperative examinations, keratoectasia could develop after LASIK. ICRS could be effective for the treatment of keratoectasia after LASIK.

Keywords: keratoectasia, LASIK, intrastromal corneal ring segments

\section{Introduction}

Keratoectasia (corneal ectasia) is known as one of the most unfavorable complications after laser in situ keratomileusis (LASIK). There is increasing concern regarding risk factors for developing keratoectasia after LASIK. Keratoconus and pellucid marginal degeneration as demonstrated by corneal topography ${ }^{1,2}$ are among significant risk factors for the development of post-LASIK keratoectasia. Besides these two diseases, a variety of other risk factors have also been reported including preoperative topographic abnormalities, low residual stromal bed thickness (RSBT), thin corneal thickness (CT), age younger than 30 years, and Sphere Equivalent (SE). ${ }^{3}$ In this report, we present two eyes of two patients that developed keratoectasia after LASIK even though their preoperative risk was low as identified by the Ectasia Risk Score System. ${ }^{3}$ In addition, both patients' corneal topographies were evaluated using Pentacam (70700 OCULUS, Wetzlar, Germany), TMS-4 (TOMEY Corp, Nagoya, Japan), OPD-Scan (ARK10000 NIDEK Co, Ltd, Aichi, Japan), and Orbscan (Bausch and Lomb, Salt Lake City, UT, USA) in order to detect patients that might develop advanced keratoconus. ${ }^{4}$ Slitlamp assessments showed that both eyes were normal. Preoperative central corneal thickness (CCT) was over $500 \mu \mathrm{m}$, RSBT was greater than $250 \mu \mathrm{m}$, and both patients were 
considered to be good candidates for LASIK according to generally accepted criteria. ${ }^{5}$

\section{Case report}

\section{Patient I}

A 24-year-old male underwent bilateral LASIK in June 2007 at Shinagawa LASIK Center in Tokyo, Japan. Preoperatively, his uncorrected visual acuity (UCVA) was 20/400 in the right eye and 20/320 in the left. His best spectacle-corrected visual acuity (BSCVA) was 20/16 with a manifest refraction of $-5.75 \mathrm{D}-0.75 \mathrm{D} \times 155^{\circ}$ in the right eye and $20 / 16$ with a manifest refraction of $-5.25 \mathrm{D}-1.0 \mathrm{D} \times 5^{\circ}$ in his left. The intraocular pressure (IOP) was $13.4 \mathrm{mmHg}$ and $11.8 \mathrm{mmHg}$, central corneal ultrasound pachymetry was $512 \mu \mathrm{m}$ and $523 \mu \mathrm{m}$, RSBT was $327 \mu \mathrm{m}$ and $345 \mu \mathrm{m}$, corneal endothelial cell destiny was $2,817 / \mathrm{mm}^{2}$ and $2,618 / \mathrm{mm}^{2}$, and the mean keratometry $(\mathrm{K})$ value was $43.75 \mathrm{D}$ and $43.75 \mathrm{D}$ in the right and left eyes, respectively. No abnormal preoperative findings were observed (Figure 1-A), and the slitlamp examination also showed both eyes to be normal.

At his one-week follow-up examination post-LASIK, the UCVA in both eyes were 20/10. At his ten-month examination post surgery, his UCVA was 20/20 in the right eye and 20/13 in the left eye.

In July 2008, the patient returned to our clinic reporting a decrease in the visual acuity of his right eye, but no problems in his left eye. Corneal topographic examinations showed inferior steepening in the right eye (Figure 1-B). The patient was prescribed hard contact lenses (HCLs), and eye drops of timolol maleate and latanoprost were administrated in both eyes. However, for several months the patient did not wear the prescribed HCLs and missed our follow-up examinations.

In July 2009, he returned again to our clinic with further declined vision in the right eye. Corneal topographical examinations showed the development of progressive keratoectasia in his right eye but no changes in the left eye. In the right eye, UCVA was 20/700 and BSCVA was 20/12.5 with a manifest refraction of $+2.00 \mathrm{D}-6.5 \mathrm{D} \times-85^{\circ}$. The IOP was $7.4 \mathrm{mmHg}$, central corneal ultrasound pachymetry $378 \mu \mathrm{m}$, corneal endothelial cell destiny $2,762 / \mathrm{mm}^{2}$, and the mean $\mathrm{K}$ value was $48.75 \mathrm{D}$ in the right eye.

In order to treat keratoectasia, KeraRings (MEDIPHACOS, Ltd, Brazil) was implanted in the right eye (Figure 2). The channels for KeraRings ICRS were created by IntraLase FS60 (Advanced Medical Optics Inc, CA, USA) with $1.50 \mu \mathrm{J}$ for the ring energy and $1.50 \mu \mathrm{J}$ for the entry cut energy. The inner diameter was set to $4.9 \mathrm{~mm}$ and its outer diameter $5.8 \mathrm{~mm}$. The channels' entry cut thickness was $1 \mu \mathrm{m}$, the incision Axis was $180^{\circ}$ and the depth in the cornea was $315 \mu \mathrm{m}$. The implantation of the two KeraRings ICRS was as follows. Superior ICRS: thickness $=150 \mu \mathrm{m}$; arc length $=90^{\circ}$; apical diameter $=5 \mathrm{~mm}$. Inferior ICRS: thickness $=300 \mu \mathrm{m}$; arc length $=160^{\circ}$; apical diameter $=5 \mathrm{~mm}$. One month after the KeraRings implantation, his UCVA had improved to 20/25

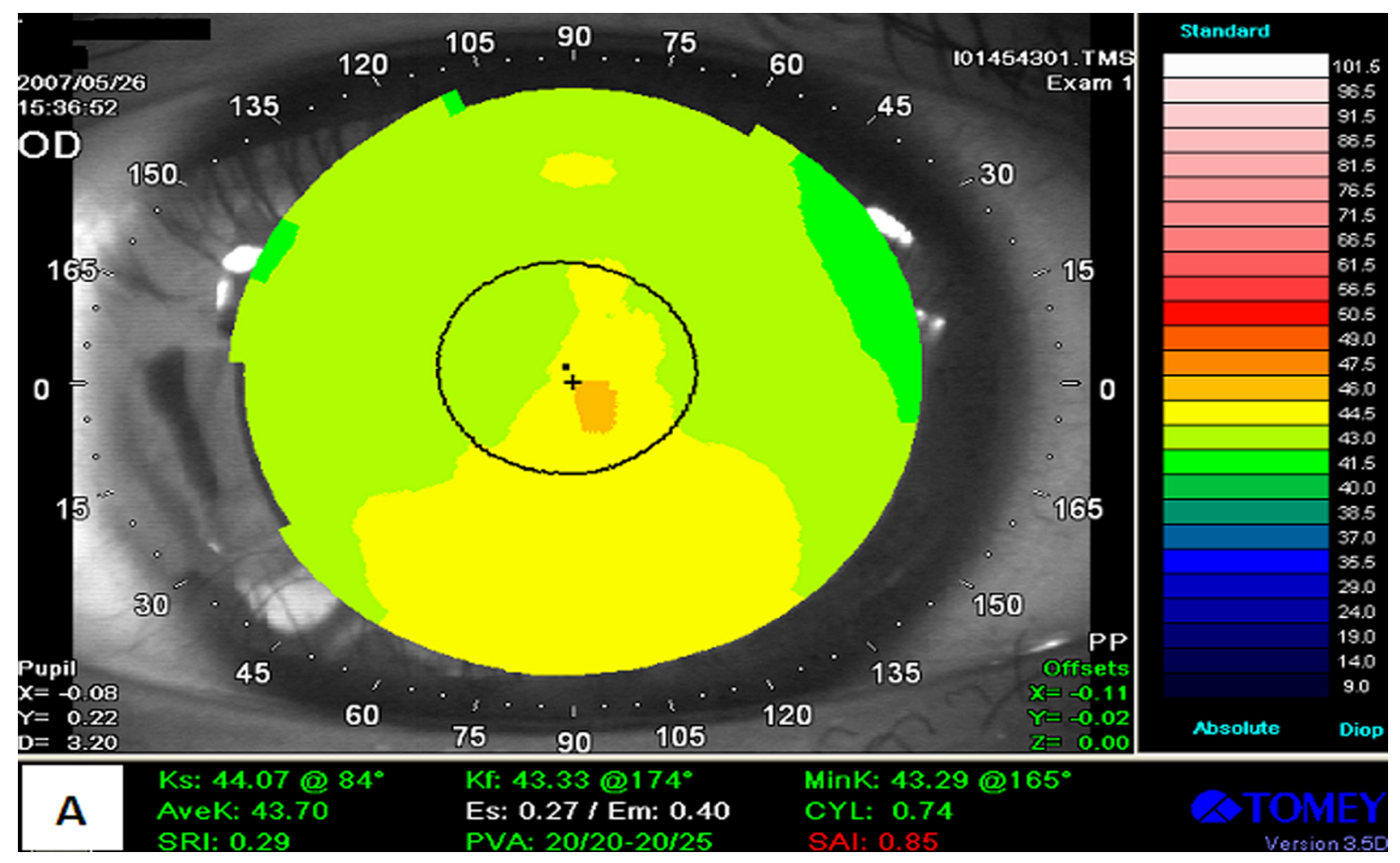

Figure I-A Patient I: Preoperative LASIK: TMS with normal elevation. 


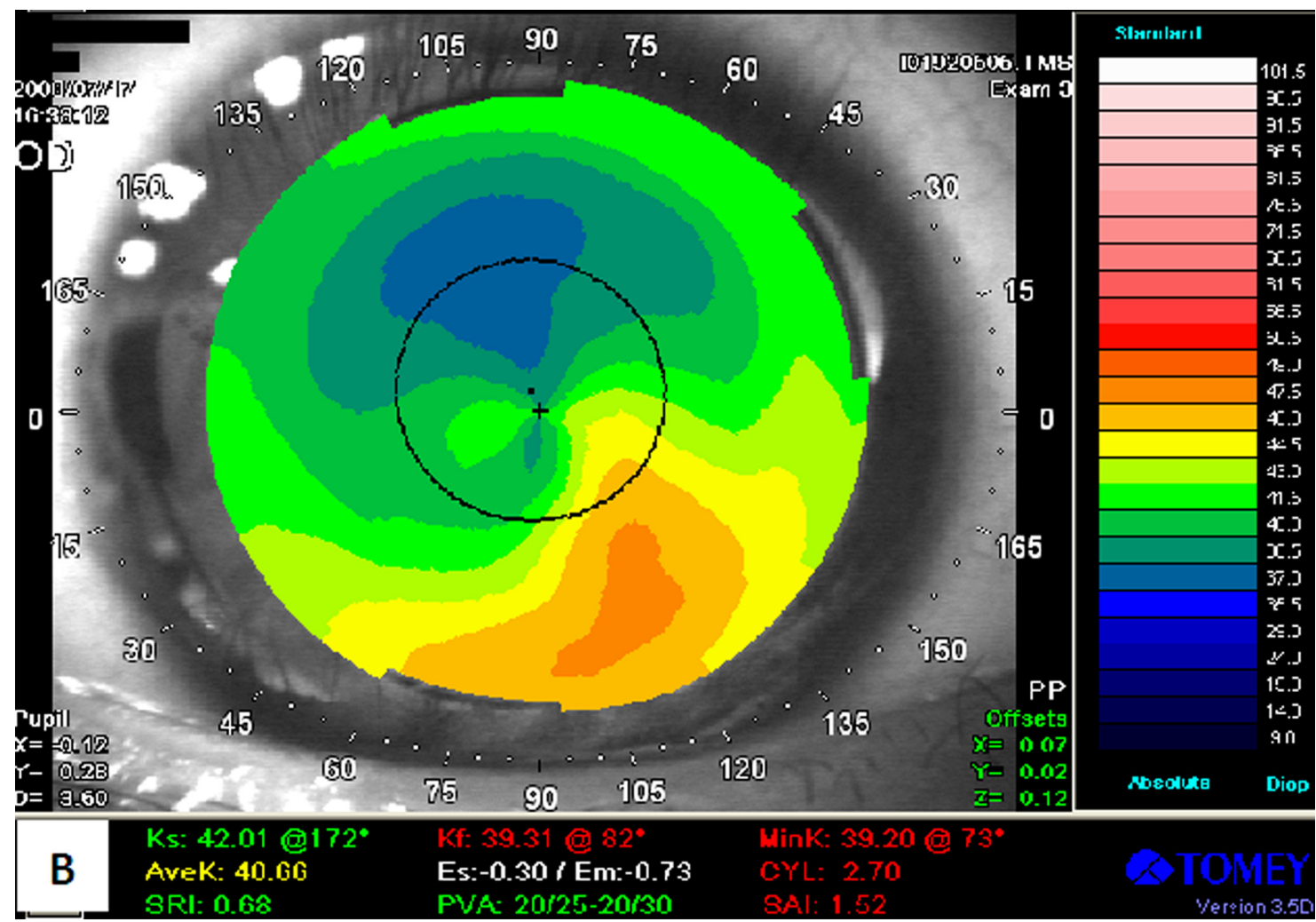

Figure I-B Patient I: TMS with inferior steeping after two years of LASIK.

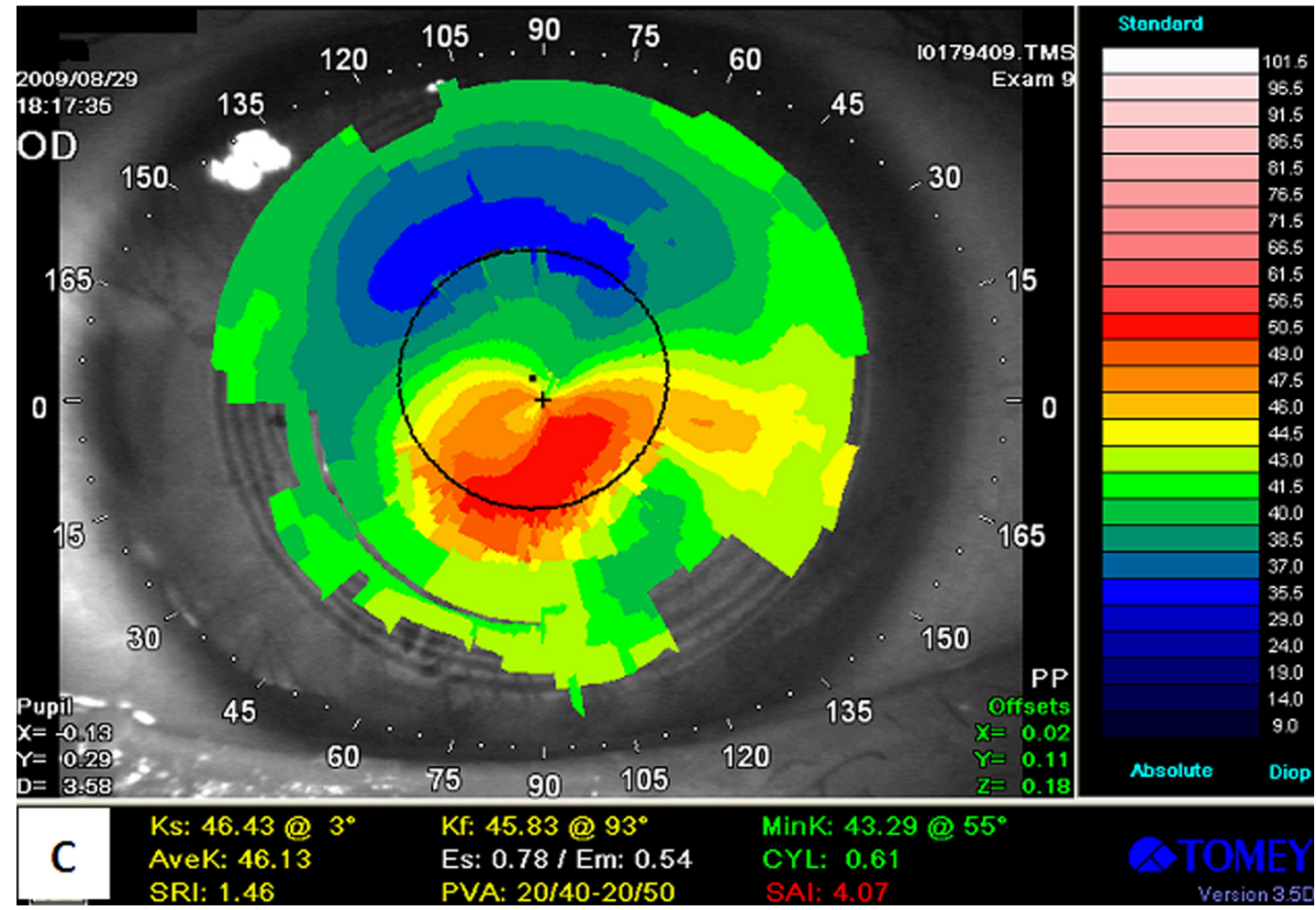

Figure I-C Patient I: Corneal curvature was changed and the uncorrected visual acuity was improved to $20 / 25$ after one month of KeraRings implanatation. 


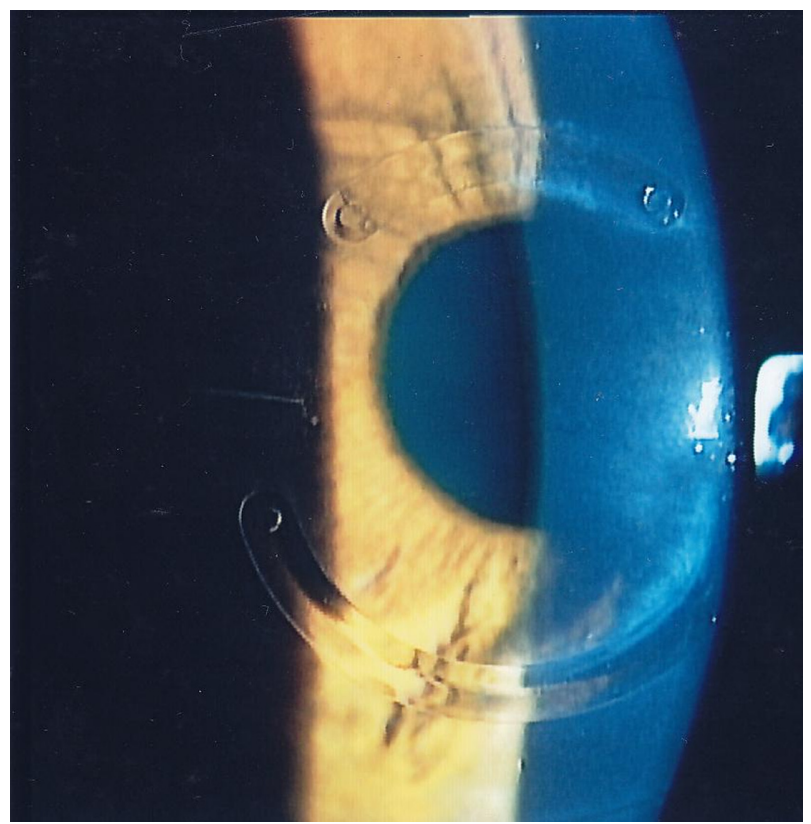

Figure 2 Patient I: Slitlamp photograph after a day of KeraRings implantation.

in his right eye, and Figure 1-C shows the improvement of the corneal curvature post KeraRing implantation.

\section{Patient 2}

A 29-year-old male underwent bilateral LASIK in June 2006 at Shinagawa LASIK Center. Preoperatively, his UCVA was 20/250 in the right eye and 20/320 in the left. The BSCVA was $20 / 12.5$ with a manifest refraction of $-7.25 \mathrm{D}-0.25 \mathrm{D} \times 95^{\circ}$ in the right eye and 20/12.5 with a manifest refraction of $-7.50 \mathrm{D}-0.50 \mathrm{D} \times 180^{\circ}$ in the left. IOP was $13.4 \mathrm{mmHg}$ and $13.1 \mathrm{mmHg}$, central corneal ultrasound pachymetry $539 \mu \mathrm{m}$ and $543 \mu \mathrm{m}$, RSBT $337 \mu \mathrm{m}$ and $338 \mu \mathrm{m}$, and the mean $\mathrm{K}$ value was 42.50D and 43.00D in the right and left eyes, respectively. The preoperative topography was normal and showed no sign of keratoconus (Figure 3-A and Figure 4). Slitlamp examination showed both eyes to be normal. The day after LASIK, the UCVA and BSCVA were 20/16 in both eyes. The patient did not return to our clinic for follow-up examinations.

He returned to our clinic in June 2008, 2 years after LASIK, complaining of progressive loss of visual acuity in the right eye. The UCVA was 20/25 and BSCVA was 20/12.5 with a manifest refraction of $-1.00 \mathrm{D}-0.5 \mathrm{D} \times 105^{\circ}$ in the right eye. Corneal topography demonstrated inferotemporal steepening in the right eye (Figure 3-B). He started to wear HCL in the right eye, and hyaluronate sodium ( $0.1 \%)$, timolol maleate, and Latanoprost eye drops were prescribed for both eyes.

Because the right vision did not improve, Intacs SK (Addition Technology Inc USA) implantation was performed in December 2008 (Figure 5). Before the Intacs SK implantation, his UCVA was 20/32 and BSCVA was 20/16 with a manifest refraction of $-1.00 \mathrm{D}-4.25 \mathrm{D} \times 90^{\circ}$ in the right eye. Central corneal ultrasound pachymetry was $406 \mu \mathrm{m}$, endothelial cell destiny $2,907 / \mathrm{mm}^{2}$, and the mean $\mathrm{K}$ value was $41.50 \mathrm{D}$ in the right eye.

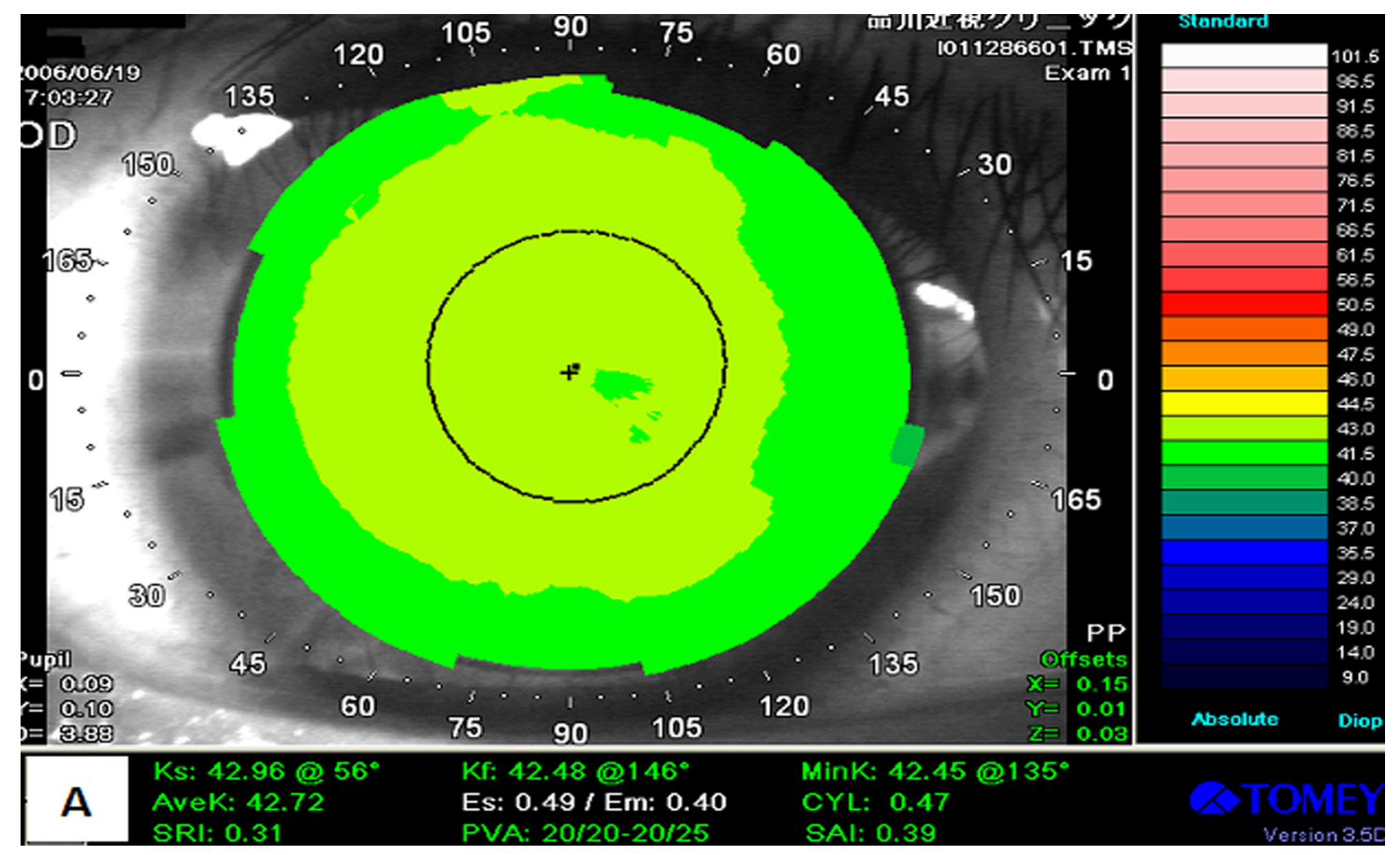

Figure 3-A Patient 2: Preoperative LASIK: TMS with normal elevation. 


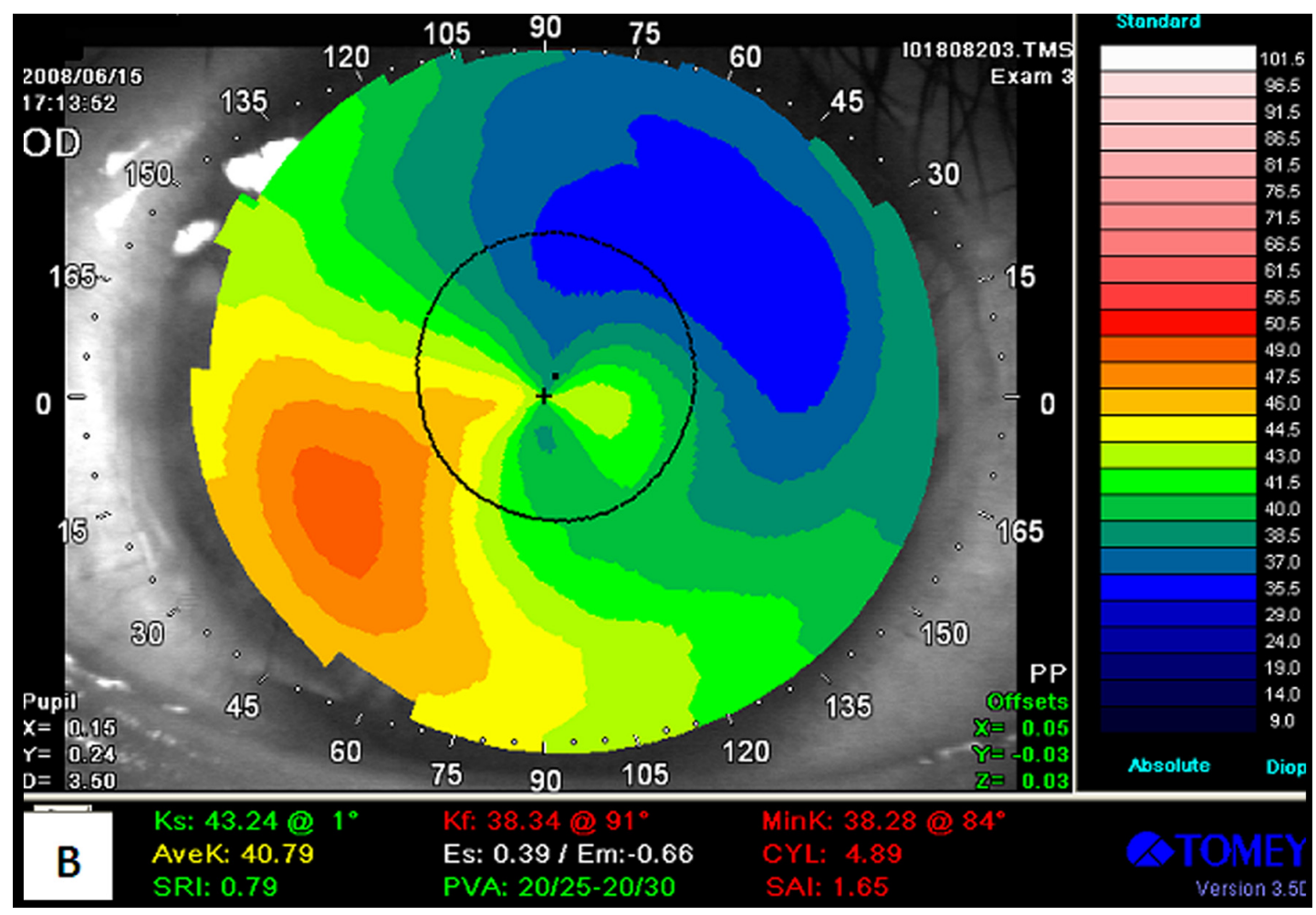

Figure 3-B Patient 2: LASIK TMS with inferotemporal steeping after two years of LASIK.

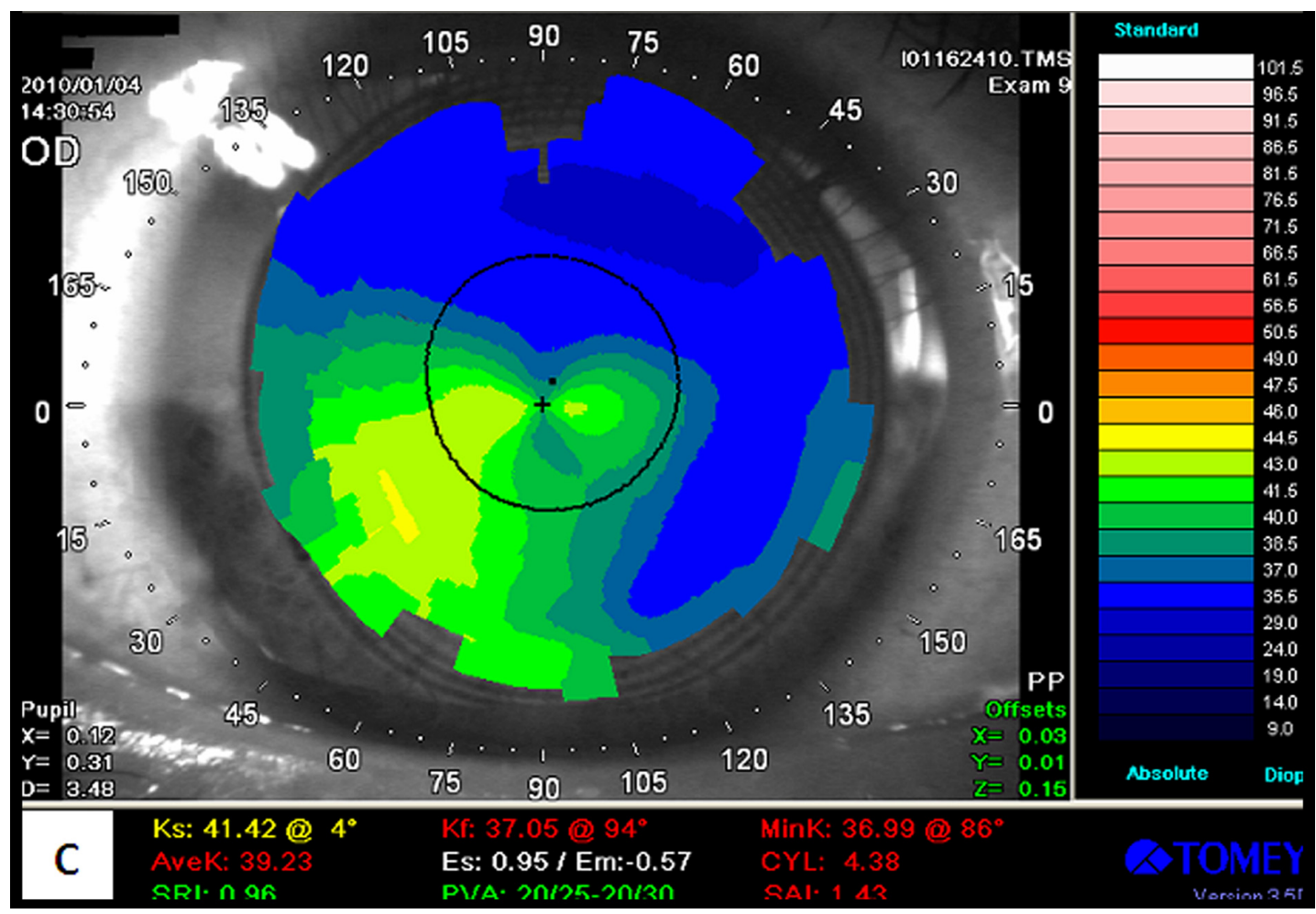

Figure 3-C Patient 2: TMS with improved inferotemporal steeping after one week of Intacs SK implantation. 


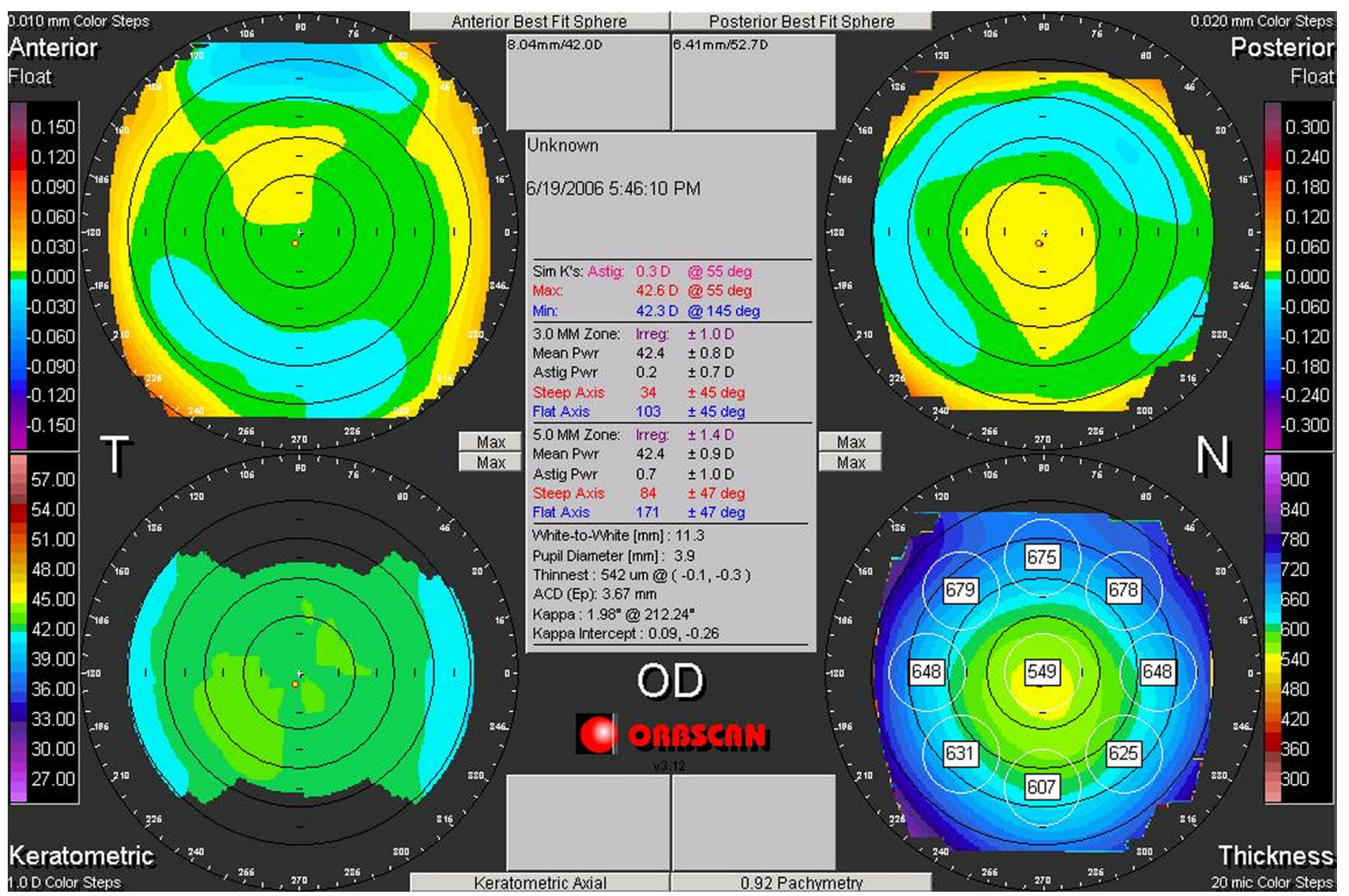

Figure 4 Patient 2: Preoperative LASIK Orbscan with normal elevation.

The Intacs SK ICRS channels were created using IntraLase FS60 with $1.80 \mu \mathrm{J}$ for the ring energy and $1.50 \mu \mathrm{J}$ for the entry cut energy. The inner and outer diameters or the channel were $6.0 \mathrm{~mm}$ and $6.8 \mathrm{~mm}$, respectively. The channel's entry cut thickness was $1 \mu \mathrm{m}$, the incision Axis $20^{\circ}$, and the depth in the cornea was $314 \mu \mathrm{m}$. Two identical Intacs SK of $400 \mu \mathrm{m}$ ICRS thickness and $150^{\circ}$ arc length were implanted superiorly and inferiorly. After the Intacs SK implantation, the patient used the prescribed soft contact lenses (SCL).

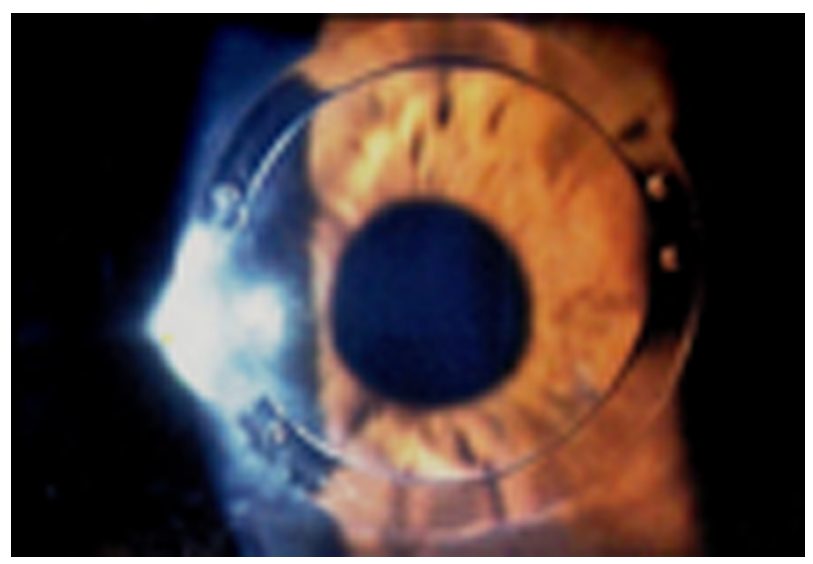

Figure 5 Patient 2: Slitlamp photograph after one week of Intacs SK implantation.
At the one-week follow-up examination, his UCVA was 20/32 and BSCVA was 20/16 with a manifest refraction of $-1.0-1.50 \times 70$ in his right eye. Three months after implantation, the corneal topographical examination revealed improvement, although central steepening was still observed (Figure 3-C). His UCVA and BSCVA were 20/32 and 20/16 with a manifest refraction of $0 \mathrm{D}-5.00 \mathrm{D} \times 90^{\circ}$, respectively. An anterior segment imaging was obtained using Visante ${ }^{\mathrm{TM}}$ OCT (Carl Zeiss Meditec Inc, Jena, Germany), which showed the positioning of ring segment was good (Figure 6). However, induced astigmatism was present in his right eye.

\section{Discussion}

LASIK has been recognized as a safe, effective, and predictable surgical procedure to treat refractive errors, and is the most commonly performed worldwide. However, there is the possibility of post-LASIK induced keratoectasia for these patients. Even after passing strict screening criteria prior to LASIK, there are still unknown risk factors. ${ }^{6,7}$ Significant risk factors have been identified for the development of keratoectasia after LASIK. These include topographic diagnosis, high refractive errors, younger age, thin RSBT, and thin central CT. In order to avoid the development of keratoectasia, these exclusion criteria may need to be expanded. 


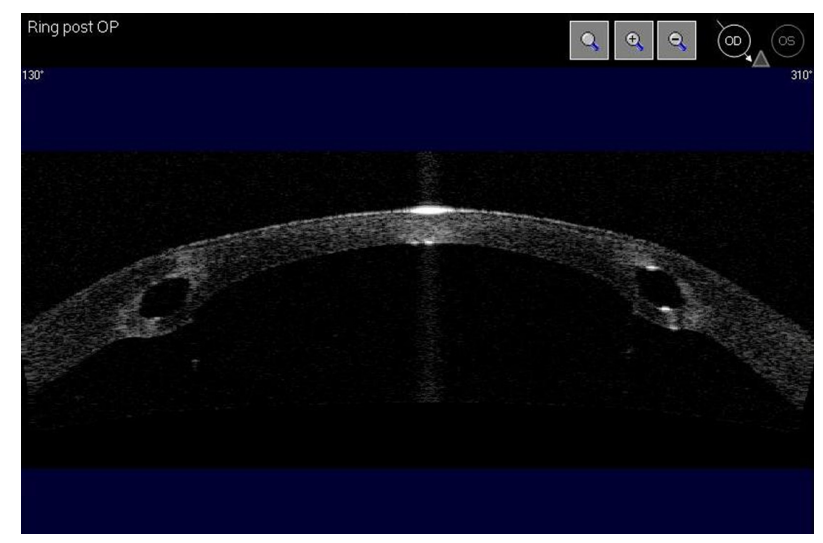

Figure 6 Patient 2: Corneal imaging using Visante ${ }^{\mathrm{TM}}$ OCT after one week of Intacs SK implantation.

In this report we described two patients who developed keratoectasia after LASIK even though thorough preoperative examinations indicated no specific risk factors. The two patients were treated by intrastromal corneal ring segments (KeraRing and Intacs SK for each patient) to correct postLASIK keratoectasia. ${ }^{8-10}$

Patient 1 achieved UCVA of 20/25 at one month after ring implantation in his affected eye; however, his UCVA decreased to 20/125 at his 5-month examination. In Patient 1, a certain improvement of visual acuity was observed after intrastromal ring implantation, but then myopic regression gradually developed, and corneal steepening was progressive over time. Continued examinations and follow-up treatments using cross linking or phakic IOL will be considered for Patient 1.

For Patient 2, after the Intacs SK surgery in his right eye, his UCVA was 20/32 at his 7-month examination. One year after the Intacs SK implantation, Patient 2's UCVA remained 20/32. Intacs SK ICRS had an effect on Patient 2 significantly.

In conclusion, post-LASIK keratoectasia can occur even in patients without specific risk factors. There have been recent reports showing that measurement of corneal hysteresis $(\mathrm{CH})$ and corneal resistance factor $(\mathrm{CRF})$ with the Ocular Response Analyzer (ORA) can detect early keratoectasia. ${ }^{11-13}$ In order to decide proper indications of LASIK, surgeons should take $\mathrm{CH}$ and CRF values into consideration besides current standard preoperative screening examinations.

\section{Disclosure}

The authors have no financial interests in the materials or products presented herein.

\section{References}

1. Ambrósio R Jr, Wilson SE. Early pellucid marginal corneal degeneration. Cornea. 2002;21(1):114-117.

2. Holladay JT. Keratoconus detection using corneal topography. J Refract Surg. 2009;25:958-962.

3. Randleman JB, Trattler WB, Stulting RD. Validation of the ectasia risk score system for preoperative laser in situ keratomileusis screening. Am J Ophthalmol. 2008;145(5):813-818.

4. Ertan A, Kamburoglu G, Colin J. Location of steepest corneal area of cone in keratoconus stratified by age using pentacam. J Refract Surg. 2009;25:1012-1016.

5. Kymionis GD, BouZoukis D, Diakonis V, et al. Long-term results of thin corneas after refractive laser surgery. Am J Ophthalmol. 2007;144(2):181-185.

6. Klein SR, Epstein RJ, Randleman JB, Stulting RD. Corneal ectasia after laser in situ keratomileusis in patients without apparent preoperative risk factors. Cornea. 2006;25(4):388-403.

7. Binder PS, Lindstrom RL, Stulting RD, et al. Keratoconus and corneal ectasia after LASIK. J Refract Surg. 2005;21:749-752.

8. Carrasquillo KG, Rand J, Talamo JH. Intacs for keratoconus and postLASIK ectasia mechanical versus femtosecond laser-assisted channel creation. Cornea. 2007;26(8):956-962.

9. Sansanayudh W, Bahar I, Kumear NL, et al. Intrastromal corneal ring segment SK implantation for moderate to severe keratoconus. J Refract Surg. 2010;36:110-113.

10. Coskunseven E, Kymionis GD, Nikolaos S, et al. One-year results of intrastromal corneal ring segment implantation (KeraRing) using femtosecond laser in patients with keratoconus. Am J Ophthalmol. 2008;145(5):775-779.

11. Kerautret J, Colin J, Touboul D, Roberts C. Biomechanical characteristics of the ectasic cornea. J Cataract Refract Surg. 2008;34:510-513.

12. Liu R, Chu RY, Zhou XT, Qu XM, Dai JH, Wang L. A compare study on cornea biomechanical properties in normal and keratoconic eyes Zhonghua Yan Ke Za Zhi. 2009;45(6):509-513.

13. Kirwan C, O'Malley D, O' Keefe M. Corneal hysteresis and corneal resistance factor in keratoectasia: findings using the Reichert Ocular Response Analyzer. Ophthalmologia. 2008;222(5):334-337. Epub 2008 Jul 15
Clinical Ophthalmology

\section{Publish your work in this journal}

Clinical Ophthalmology is an international, peer-reviewed journal covering all subspecialties within ophthalmology. Key topics include: Optometry; Visual science; Pharmacology and drug therapy in eye diseases; Basic Sciences; Primary and Secondary eye care; Patient Safety and Quality of Care Improvements. This journal is indexed on
PubMed Central and CAS, and is the official journal of The Society of Clinical Ophthalmology (SCO). The manuscript management system is completely online and includes a very quick and fair peer-review system, which is all easy to use. Visit http://www.dovepress.com/ testimonials.php to read real quotes from published authors. 